
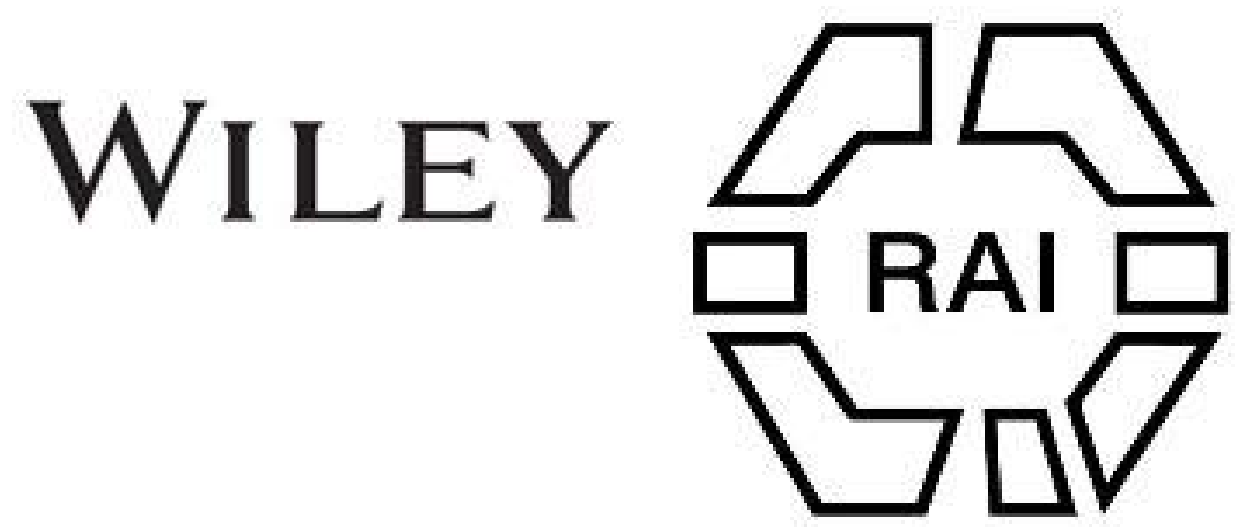

16. A Further Note on the Use of the Wooden Trumpet in Papua.

Author(s): W. N. Beaver

Source: Man, Vol. 16 (Feb., 1916), pp. 23-25

Published by: Royal Anthropological Institute of Great Britain and Ireland

Stable URL: http://www.jstor.org/stable/2787630

Accessed: 25-06-2016 11:36 UTC

Your use of the JSTOR archive indicates your acceptance of the Terms \& Conditions of Use, available at

http://about.jstor.org/terms

JSTOR is a not-for-profit service that helps scholars, researchers, and students discover, use, and build upon a wide range of content in a trusted digital archive. We use information technology and tools to increase productivity and facilitate new forms of scholarship. For more information about JSTOR, please contact support@jstor.org.

Wiley, Royal Anthropological Institute of Great Britain and Ireland are collaborating with JSTOR to digitize, preserve and extend access to Man 
death (this is done in Upper Burma also) immediately after removal of the body, and along the path from the house to the gate of the compound. As water frequently takes the place of blood in Buddhist ceremonies, both these customs may perhaps be regarded as a survival of the practice of killing slaves on the death of their master.

The Burmese appear to have no ideas regarding the direction of the land of the dead, or of the country from which the race came.

The curious device of holding a complete funeral and burial ceremony in the hope of deceiving the Destroyer, and inducing him to leave a sick person alone, was fully described in MAN, 1909, 13, under the heading "Cheating Death."

The Burman regards it as a matter of course that the soul should continue to exist after death, and he believes that it remains in the house, and is cognizant of all that goes on there, for seven days. The bed of the deceased person is laid, and a fresh supply of food and water is placed by it every morning and evening. During the same period hospitality is offered to all who come, and monks are invited to preach as well as to eat. At the end of the seven days the spirit departs. According to my principal informant, he is ejected by the house-god, Min Magayi, the mighty blacksmith who was burnt alive by a king of Tagaung, and whose spirit watches over every Burman household. But during the seven days he is not absolutely confined to the house. He may wander about visiting the places he was wont to visit in life.

In 1907 the Civil Surgeon of Pyapon died while I was Deputy Commissioner of the district. He was a native of Arakan. The day after bis death a messenger came to me from his widow asking me whether I would sign an order discharging. him from Government service. The reason given was that his ghost had been walking about the hospital and disturbing the patients there. Until he was removed or allowed to resign be was still under the orders of his superior officers, and considered it his duty to go on with his work. I objected that I had no power to remove a Civil Surgeon, but was told that my order would be quite effective for the purpose. Of course I consented; but I was somewhat startled a little later when an official letter was placed before me, addressed to the dead man and informing him that he was removed from Government service, with effect from an hour and date mentioned, these being the hour and date at which he died. I signed the letter, and was told afterwards that it had had the desired effect.

A creditor has a better chance of recovering a debt from the dead than from the living, provided the deceased has relations who are concerned for his welfare. If the debt is not paid it is believed that the dead man will come into the creditor's power, as his slave (nowadays servant), his ox, or his dog. R. GRANT BROWN.

\section{A further Note on the Use of the Wooden Trumpet in Papua. If}

In MAN, 1915, 11 (February), Dr. Seligman discusses the wooden trumpet as used on the southern slopes of the Hydrographers Range. A few remarks on the further distribution of this instrument may be of interest.

Dr. W. M. Strong, from whom Dr. Seligman obtained the specimen figured in MAN, states that he knows of the use of the wooden trumpet only in the region quoted, but I am able to point out from personal knowledge that its distribution is very much wider.

Naturally, the coast tribes use the ordinary conch shell as a trumpet, and the people of the hinterlands obtain their shell instruments from them in the way of trade; but the further one penetrates inland, the more difficult it becomes to obtain shells. I have found the wooden trumpet, almost identical with the instrument figured by Dr. Seligman, used over a large portion of the alministrative Northern 
Division of Papua; that is to say, throughout the region directly between the Hydrographers Range and the boundary of British Papua. To quote a few examples, I have found it used, together with the conch, among the Sangara on the northern side of Mount Lamington, among the Huhurundi living inland from Holnicote Bay, and among the Howajega, Asingi, and Tohani, all bordering about the main Kumusi River. In the trans-Kumusi region, towards the Yodda Valley, I find that the Autembo and other tribes use it more frequently than the conch. Only a week or so ago $I$ found it in use in the valley of the Mamama, a tributary of the Kumusi rising on the southern side of Mount Lamington. I have also seen it used on both the middle and upper Waria, in what was formerly German New Guinea.

Now this is a tolerably wide distribution, and under no circumstances can the users be claimed to have had any communication with the Southern Hydro-

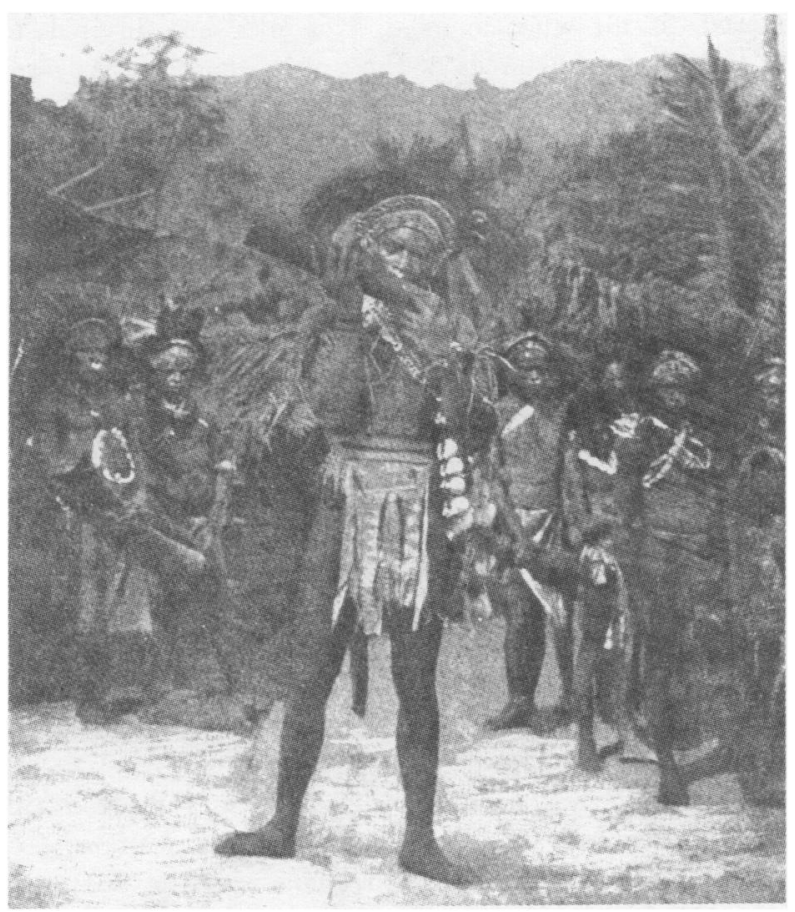
graphers tribes. Of course it should be understood that the conch shell is also used.

I have a note that a bamboo tube is used instead of the wooden instrument among the Andakofu tribe (Sauni) in the trans-Kumusi region.

The ordinary conch shell trumpet varies in size up to about 20 inches long and about 9 inches across in the largest part. A hole from 1 inch to $\frac{3}{4}$ inch in diameter is made about 3 inches from the apex. Over water the reverberating note can be heard a very considerable distance.

Some details of the notation of trumpet blowing might be of interest. Of course, neither the drum nor trumpet "language" is in any degree as rich as what $I$ understand the West African drum "talk" is-in fact, the Papuan variety is very poor indeed, but it should be understood that certain distinct siguificance is attached to different notes or calls. This notation is chiefly on the longshort blast system, and I give some examples of shell trumpet calls from the Binandele tribes of the Mamba and Gira rivers. Naturally the significance varies according to the district :-

(1) After killing in a fight when in camp and dancing:

$$
\text { blast, \&c.). }
$$

(2) Calling to a fight, summoning to a fight, and going to a fight :

$$
\text { - }
$$

(3) Conveying the news of a death :

$$
-\frac{1}{-}-(\text { i.e., short, long, short long, \&c.). }
$$

(4) Men are bringing a pig :

$$
--1 \text { (i.e., long, short, long, \&c.). }
$$


Nowadays No. 2 is generally used to call in the people from their gardens, say, for example, on the arrival of European or other strangers, or, again, half-a-dozen long blasts may convey the news that a Government party or Europeans are approaching.

W. N. BEAVER.

\section{Palestine: Archæology.}

Lewis.

A Note on Megalithic Monuments. By A. L. Lewis.

The questions raised by Mr. Peet and Professor Elliot Smith respecting megalithic monuments are so important that $I$ should like to be allowed to state the conclusions to which I have been led by a study of the monuments, and of the literature concerning them, extending over fifty years. They are :-

(1) The origin of building with large stones need not have been, and probably was not, confined to one centre.

(2) The vast extent of the countries in which building with large stones, whether worked or unworked, was practised, and the different ways in which it was applied, show that it was a local or tribal rather than a racial custom.

(1) Such inventions as those of the mariner's compass, gunpowder, and the steam engine (the latter specially cited by Professor Elliot Smith) seem to have been in process of evolution in different places, though perhaps only brought to perfection in one of them. But was the commencement of megalithic construction an invention in the same sense as either of those? The first inhabitants, however uncivilised, of any stony country might surely begin to pile stones together to form dwellings, enclosures of any kind, and perhaps tombs; and they would, in the absence of mortar or cement, soon find that the larger were the stones, the better buildings they made, and, when they had overcome the difficulty of handling them, they would often use the largest they conld get. This is surely a thing that might have occurred anywhere and many-where. When an efficient cementing material was introduced the use of small stones became much easier, though that of large stones in various forms was, and still is, retained. It might be safer to argue that the epoch-making discovery or invention made only in one centre was that of mortar or cement.

(2) Mr. Peet seems to construe the term megalithic rather strangely, but it is very difficult to draw a distinction, based only upon the size of the stones, between monuments of a similar appearance, and I therefore prefer the term "rude stone monuments," even though some of them are more or less worked. In my view it is building without mortar, with large or small stones, or a mixture of both, that is the distinctive phase of culture of which the special characters insisted upon by Mr. Peet are but local or tribal variations. Rude stone monuments are found in many and various parts of Europe, Asia, Africa, and America, and in Australia and the Pacific Islands-altogether too much ground to be covered by any one prehistoric race or by the influence, direct or indirect, of any such race. But, although rude stone monuments are found in so many different places, their characters differ and are often much localised. The great circles, the primary purpose of which was not sepulchral, are practically confined to the British Isles; there is nothing elsewhere that can be compared with Avebury, Arborlow, Stanton Drew, Stonehenge, Brogar, or with many of our smaller circles. If we turn to monuments which were unquestionably sepulchral, we find dolmens of various sorts by the hundred in Ireland, France, Algeria, India, \&c., many in Wales, but practically none in the eastern half of England, except in one corner of Kent, where there are some 